\title{
The Effectiveness Use of Virtual Reality Media in Physics Education of Solar System Towards Cognitive Learning Outcomes
}

\begin{abstract}
Sigit Dwi Saputro ${ }^{*}$, Agung Setyawan ${ }^{2}$
${ }^{1}$ Pendidikan informatika, Universitas Trunojoyo Madura, Bangkalan, Indonesia

${ }^{2}$ Pendidikan Guru Sekolah Dasar, Trunojoyo Madura, Bangkalan, Bangkalan, Indonesia

e-mail: sigitd.saputra@trunojoyo.ac.id, agung.setyawan@trunojoyo.ac.id

Abstract

Digital literacy skills in the context of mastering the use of digital media were needed to streamline achievements in learning. One of the digital medias that can be applied in abstract learning is virtual reality. The purpose of this research was to determine the effectiveness of cognitive learning outcomes which include the presence or absence of the influence of the use of virtual reality media, the completeness of learning outcomes based on KKM and the completeness of classical learning outcomes. This type of research was pre-experimental by using one group pre-test post-test design. The sample used was class VIII Al-Asyari Technology Middle School which consists cof only one class. The instruments used in the study include description tests. The effect of learning outcomes was analyzed by t-test using SPSS, learning outcomes will be analyzed based on the Minimum Completion Criteria (KKM) and classical completeness while learning motivation was analyzed quantitatively. The results showed that physics learning using effective virtual reality media on learning outcomes as evidenced by the influence of virtual reality media on results with a significance of 0.000 , learning outcomes reached the KKM value of 75 with an average yield of 88.1. Classical learning completeness obtained a percentage of results of $86.3 \%$ included in the excellent category.
\end{abstract}

Keywords: Media Virtual Reality, Structure, Learning Outcomes

\section{Introduction}

Physics is part of Natural Sciences subjects, at the junior high school level learning objectives have been determined by the Ministry of Education and Culture. The purpose of learning science is to understand simple science concepts and still maintain religious values. The concept of simple science will be used to solve problems of the surrounding scientific phenomena, while students' religiosity is expected to be able to connect natural phenomena with the greatness of an almighty god (Hidayatullah, 2018; Yusriyah, 2015).

One of the competencies that must be mastered by students in the 2013 curriculum in physics is the solar system. In the appendix of the Minister of Education and Culture for class VIII, there is a range of core and basic competencies related to the solar system. The third core competency is to understand and apply knowledge (factual, conceptual, and procedural) based on the curiosity about science, technology, art, culture related to phenomena and events that appear to the eye. The fourth, processing, presenting, and reasoning in concrete domains (using, parsing, arranging, modifying, and making) and abstract realms (writing, reading, counting, drawing, and making) under what is learned in school and other sources in the same perspective/theory (Poniman, 2016; Susanti \& Jatmiko, 2016).

Material characteristics in the learning of the solar system which is expected students understand the differences in gravity and the orbital path of each planet (Williamson \& Willoughby, 2012; Yu ka Sahami \& Denn G, 2010). So that the spatial ability is needed to master the solar system material, this is due to the material the solar system cannot observe directly (Hegarty, 2010; Shen, J. \& Confrey, 2010). The material of the solar system is an abstract lesson because students cannot feel the conditions in a real way towards objects contained in the solar system. If students are only given theory, it will have an impact on each student's concept dissimilarity. Then what needs to be considered by every teacher is designing the learning process appropriately.

\footnotetext{
${ }^{*}$ Corresponding author.

Received 20 January 2020; Accepted 01 August 2020; Available online 1 September 2020 (c) 2020 JPI. All Rights Reserved
} 
The results of an interview with a physics subject teacher in one of the junior high schools in Bangkalan district showed that the learning process in solar subjects uses textbooks. Besides, teachers also use video media to deliver material related to the planet. The learning process that has been carried out so far makes students feel bored and even less interested in listening to the material delivered by the teacher. Students cannot understand that each planet has a different speed, gravitational differences between planets, and the planet can rotate following the stability of its orbit (Plummer et al., 2015). Besides, there are 98\% of students experiencing misunderstandings related to the distance of planets in the solar system (Schneps et al., 2014). Still found a serious error when teaching solar system material that the teacher uses a piece of paper and then draw the types of planets (Shen \& Confrey, 2010). The method does not provide a learning experience for students. Students are passive and only receive information conveyed by the teacher.

Teachers can use a variety of ways to be able to present space life. One way to present space life is to create a learning medium. In full, learning media are defined as physical or nonphysical tools used as intermediaries between teachers and students in understanding learning material to be more effective and efficient, so that learning material is quickly accepted by students and arouses interest in further learning (Musfikon, 2012). Learning media is a component of learning resources or physical vehicles that contain instructional material in the student environment that can stimulate students to learn (Arsyad, 2013).

Thus, in the learning process requires media to explain a concept. Learning media can also have an impact on several aspects obtained by students, including cognitive, social, and emotional competencies (Balkun, 2011). Cognitive competence is related to student learning outcomes. The effectiveness of learning outcomes is influenced by student goals and knowledge. Learning objectives will be evaluated both in detail for each individual and the general picture through several samples which asked by educators (Hamdani, 2011). While knowledge can be measured by evaluating formal learning both through a midterm and the end of the semester.

Solar system learning requires special media to learn science to students. The things that affect the cognitive abilities in learning the solar system one of which is the media. Media that needs to be considered in the design is related to the size and position of the perspective of the use of the media by students (Yu et al., 2016). Improving the quality of learning requires the ability of the teacher to master the material, structure, concepts, and scientific mindset that supports the subjects taught develops learning materials that are taught creatively and utilizes information and communication technology to develop themselves.

The development of Science and Technology has an impact on rapidly changing information technology. The limitations of the five senses in the solar system required threedimensional media (Dahsah \& Phonphok, 2012). One example of technology that can be created in three-dimensional learning media is Virtual Reality. Helps define what is often referred to as "Virtual Reality". This is a computer-based technology that combines special input and output devices so that users can interact deeply with virtual environments as if they were in the real world (Susilowati, 2017). Virtual reality media are needed because of limited hardware media (Papachristos, Vrellis, \& Mikropoulos, 2017; Ashfaq Amin, Diane Gromala, Xin Tong, 2016).

Virtual reality is a technology that allows users to interact with the environment of computer simulation results in cyberspace which can evoke an atmosphere of three or even four dimensions. So that users seem to be directly involved physically in the environment. Virtual Reality can be the right choice for learning media that cannot be reached by human hands (Susilowati, 2017). The benefits of applying Virtual reality to the learning process can have a real effect on students' experiences (Shi et al., 2019). By using Virtual Reality technology we can create a space environment (Bailey \& Bailenson, 2017). Students find it difficult to make observations related to the solar system so that virtual effects must be packaged in virtual reality (DeJong, 2017; Makransky, G. Lilleholt, 2017).

The use of virtual reality media has a positive impact on student understanding (Leder et al., 2019). Simulation of the use of virtual reality gets better learning outcomes than traditional learning (Clark, B. Tanner-Smith, E. Killingsworth, 2016). This causes the experience of using these media to make learning meaningful so that cognitive abilities increase (Alahabi, 2016; Passig, D. Tzuriel, D. \& Eshel-Kedmi, 2016; Webster, 2016). 
Besides, learning using virtual reality learning media affects students' cognitive (Leder et al., 2019). Virtual reality becomes unique learning Maximize the long-term memory ability of students (Valdesolo et al., 2017). Other benefits include improving students' spatial ability (Jang et al., 2017). This is inseparable from the role of virtual reality that can make classes active and interactive (Leder et al., 2019). This shows that the visualization effect provided by virtual reality media can provide an understanding of material concepts. Because the advantages of using virtual reality media over video or other image media have a more detailed display of content that can visualize three dimensions (Gavish et al., 2015).

Theoretically, the use of virtual reality media is better than using video media because students can learn interactively (Chittaro \& Buttussi, 2015; Buttussi \& Chittaro, 2018). Things that need to be considered when before the use of virtual reality is the presence of breafing first of its use procedures to reduce the sense that arises as an adaptation to new media (Lackey, Salcedo, Szalma, \& Hancock, 2016; Breedt \& Labuschagne, 2019). Learning using virtual reality media has an impact on student motivation (Makransky, G. Bonde, M. T. Wulff, J. S. G. Wandall, J. Hood, M. Creed, 2016; Makransky, G., Thisgaard, M. W., \& Gadegaard, 2016; Thisgaard, M. \& Makransky, 2017; Shapira, Amores, \& Benavides, 2016). The impact of motivation is linear to student learning outcomes (Pekrun, 2016; Holley, Hobbs, \& Menown, 2016). If learning has led to the addition of individual student interests this will have an impact on the optimal learning process (Renninger, K. A; \& Hidi, 2016).

Virtual reality media is one type of digital media. In general, digital media has several advantages, among others. Therefore, digital media can have opportunities for more effective teaching processes. Some things that need to be considered in the practice of learning to use digital media related to social, feelings of love, and ethics. So in developing digital technology, an educator must think of ways of presenting information that is effective, interesting to improve the learning process, and still maintain a structured way of thinking, attitudes, social practices, and bold practices in real experiments (Arsyad, 2013). There are main components that must be designed by an educator when using digital media, namely developing critical thinking skills, developing communication skills, developing creativity, and student-centered learning (Balkun, 2011; Hirsh-pasek, Zosh, Michnick, Gray, \& Robb, 2015).

The benefits of implementing digital media are improving skills in using technology (Schmid \& Petko, 2019). The study involved 31 schools with 879 students who wanted to find out how the impact of open teaching methods that apply digital technology can enhance digital skills and ICT confidence in learning. Schools that use open teaching methods show that there is an increase in students in using ICT when in school. This means that students become accustomed to using ICT when a teacher applies an open teaching method. Automatically, they use ICTs to dig up information or find solutions to tasks. This shows that students are skilled in using digital. The high frequency of using ICT also shows that students begin to have perceptions related to self-efficacy and positive attitudes towards ICT as a tool for learning.

The function of the application of digital media influences metacognition in the learning process (Norman \& Furnes, 2016). Research that has been done is to find out the results of metacognitive comparisons between those who use digital or non-digital. Both can be measured in digital or non-digital relations after being given a short linear text reading. The metacognitive indicators measured are forms of self-regulation and learning in different study contexts. Although digital usage has limited scope in reading text that appears on the screen but in the form of a linear text can have the same impact on students' metacognitive abilities. This finding implies that there is an important note for teachers to better adapt to digital media because it empirically impacts on students' metacognition, and more importantly, is how to design in digital media so that it is more focused on student metacognition.

Based on the benefits of using virtual reality media that have been explained, then the effectiveness of using this media in solar learning will be measured. Effective learning is a learning strategy that is used to measure the extent to which learning objectives can be achieved. Effective learning is a measure of teacher success in managing classes (Nurjanah \& Poernomo, 2016; Derlina \& Mihardi, 2015; Nur, 2015). Effectiveness relates to goals or objectives determined from the beginning before the learning process is measured through achievement tests. So meaningful 
effectiveness produces effects or effects of learning treatment. Thus, effective learning is learning where goals are achieved.

Evaluation of Learning Outcomes by Educators in Primary and Secondary Education Article 8 paragraph 1 states, the completeness of learning outcomes is the level of attainment of minimum attitudes competencies, knowledge competencies and skills competencies which include completeness of mastery of material and mastery of learning in the context of the study period (Sarah, 2019; Hasanah et al., 2017; Kustijono \& HM., 2014). This study measures the effectiveness of cognitive learning outcomes in drawing virtual reality media in solar system subjects. The effectiveness of learning outcomes is limited by three things, there are the influence of the use of virtual reality media on learning outcomes, learning outcomes exceed the minimum completeness criteria (KKM) ie a score of 75 and, learning outcomes exceed the classical completeness of $75 \%$.

\section{Method}

Research at Al-Asyari Technology Middle School, Kwanyar District, Bangkalan Regency. This research was experimental research using one group pre-test post-test design. The treatment is the provision of Virtual Reality media during the learning process. Research subjects included populations and samples. The population in the study was all students in Al-Asyari Technology Middle School which consisted of one class with 22 students. The sampling technique used in this study was saturated sampling. This study used a saturated sample which was taking all samples because the population was less than 100 .

The instrument used to measure student learning outcomes was the description test. Making questions focus on Basic Competency 3.2 namely Describe the solar system, the sun as the center of the solar system, as well as the position and characteristics of members of the solar system. Instrument grid as Table 1.

Table 1. Test instrument Grid

\begin{tabular}{clc}
\hline No & \multicolumn{1}{c}{ Indicator } & Number of Question \\
\hline 1 & Explain the order of the solar system & 2 \\
2 & Explain the basic concepts of the sun & 1 \\
3 & $\begin{array}{l}\text { Understand the positions and characteristics of solar } \\
\text { system members }\end{array}$ & $3,4,5$ \\
\hline
\end{tabular}

The results of the implementation of the to find out the level of influence of giving virtual reality media tests to the results, the effect of learning outcomes is analyzed by t-test using SPSS.

\section{Results and Discussion}

\section{Learning Outcomes Pre-Test Data}

This data was obtained through learning outcomes tests. To find out the frequency distribution of learning outcomes before using virtual reality media was presented in Table 2 and Figure 1.

Table 2. Data on Student Learning Outcomes before using virtual reality media

\begin{tabular}{cccc}
\hline No & Interval Class & Frequency & Percentage \\
\hline 1 & $30-39$ & 1 & $5 \%$ \\
2 & $40-49$ & 7 & $32 \%$ \\
3 & $50-59$ & 8 & $36 \%$ \\
4 & $60-69$ & 3 & $14 \%$ \\
5 & $70-79$ & 3 & $14 \%$ \\
\hline \multicolumn{4}{l}{} \\
\hline
\end{tabular}


It appears that the learning outcomes data before the use of virtual reality have the highest frequency with 8 students in the 50-59 interval. The lowest frequency is 1 student in the 30-39 interval. Then the histogram is presented in Figure 1.

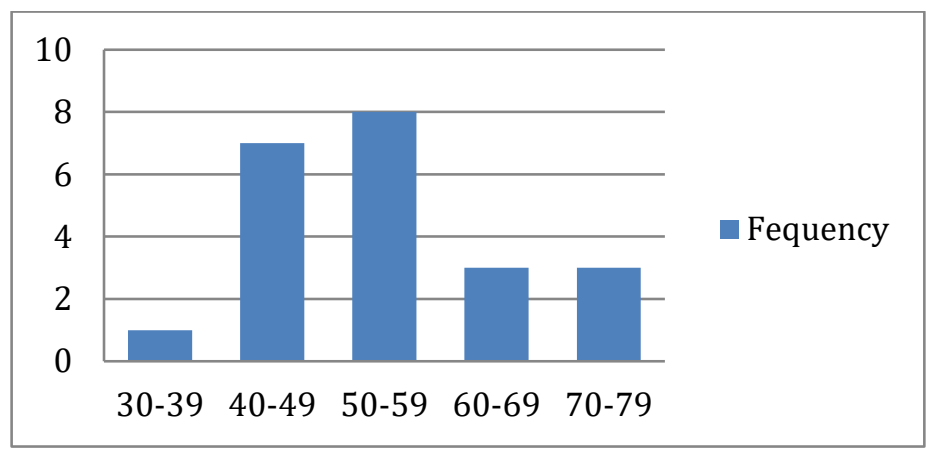

Figure 1. Histogram of learning outcomes before using virtual reality media.

\section{Learning Outcomes Post-Test Data}

This data is obtained through learning outcomes tests. To find out the frequency distribution of learning outcomes after using virtual reality media is presented in Table 3 and Figure 2. It appears that the learning outcomes data after the use of virtual reality have the highest frequency with 9 students in the $92-100$ interval. The lowest frequency is 1 student in the 72-78 interval.

Table 3. Data on Student Learning Outcomes after using virtual reality media

\begin{tabular}{cccc}
\hline No & Interval Class & Frequency & Percentage \\
\hline 1 & $65-71$ & 3 & $14 \%$ \\
2 & $72-78$ & 1 & $5 \%$ \\
3 & $79-85$ & 6 & $27 \%$ \\
4 & $86-92$ & 3 & $14 \%$ \\
5 & $92-100$ & 9 & $41 \%$ \\
\hline & Total & $\mathbf{2 2}$ & $\mathbf{1 0 0} \%$ \\
\hline
\end{tabular}

Then the histogram is presented in Figure 2.

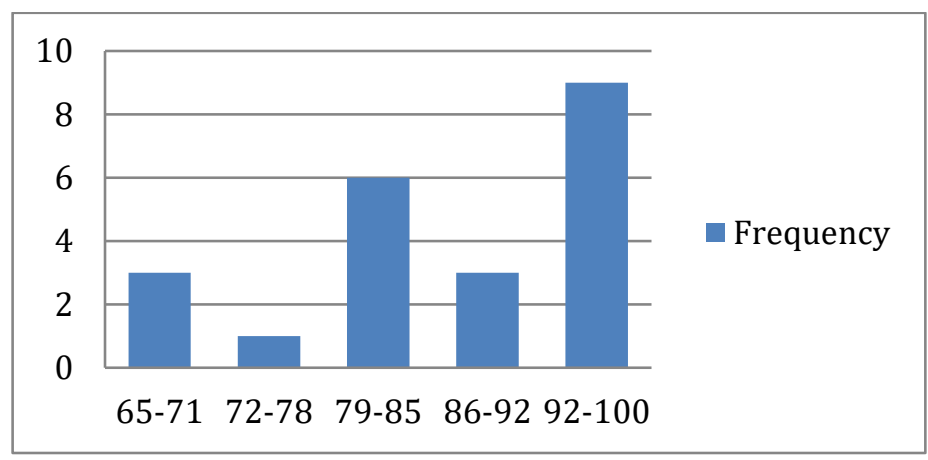

Figure 2. Histogram of learning outcomes after using virtual reality media

\section{A summary of the results of the pretest and posttest}

The description of the learning outcome data presented includes the comparison Pre-test and post-test scores as in Table 4 . 
Table 4. Description of learning outcomes data using virtual reality media

\begin{tabular}{lccccc}
\hline Condition & Total & \multicolumn{3}{c}{ Learning Outcomes } & Standard \\
& Data & Max. & Min. & Average & $\begin{array}{c}\text { Aviation } \\
\text { Devion }\end{array}$ \\
\hline Pre Test & 22 & 75 & 30 & 52,27 & 12,05 \\
Pos Test & 22 & 100 & 65 & 88,18 & 11,8 \\
\hline
\end{tabular}

In Table 4, the comparative data on learning outcomes pre-test with post test using virtual reality media. For pre-test the highest learning outcomes with a score of 75 , while the lowest score is 30 , the average score is 52,27 and the standard deviation is 12.05 . For post test the highest learning outcomes with a score of 100 , while the lowest score is 65 , the average score is 88.18 and the standard deviation is 11,18 . Based on these data it can be concluded that the learning outcomes of the solar system using virtual reality media are greater than before using the media.

\section{The effect of the use of virtual reality media on learning outcomes}

First, related to the influence of using virtual reality media on learning outcomes. Before testing the hypothesis, the researcher conducts the normality test beforehand on the collected data. Based on the normality test for the results of data using SPSS in Table 5.

Table 5. Normality Test Results

\begin{tabular}{ccccc}
\hline No & $\begin{array}{c}\text { Normality } \\
\text { test }\end{array}$ & $\begin{array}{c}\text { (Kolmogorov- } \\
\text { Smirnov }^{\mathbf{a}} \text { ) } \\
\text { Alpha }=\mathbf{0 , 0 5}\end{array}$ & $\begin{array}{c}\text { (Shapiro-Wilk) } \\
\text { Alpha }=\mathbf{0 , 0 5}\end{array}$ & Conclusion \\
\hline 1 & Pre-Test & $0,118>0,05$ & $0,284>0,05$ & Normal Data \\
2 & Post Test & $0,001<0,05$ & $0,005<0,05$ & Data Not Normal \\
\hline
\end{tabular}

The test items for the pre-test both the Kolmogorov-Smirnov and Shapiro-Wilk test results are included in the normal category, while the post-test both the Kolmogorov-Smirnov and Shapiro-Wilk test results are not normal.

As for the homogeneity test of learning outcomes between before using virtual reality media (pre-test) and after virtual reality media (post-test) as Table 6.

Table 6. Homogeneity Test Results

\begin{tabular}{ccc}
\hline Significance & Decisions & Conclusions \\
\hline $0,73>0,05$ & $\begin{array}{c}\text { Cognitive }=\text { Ho } \\
\text { rejected }\end{array}$ & Homogeneous \\
\hline
\end{tabular}

Table 6 shows that homogeneity testing on learning outcomes. The P-value (significance of the dependent variable) is more than (>) 0.05 , so it was decided that Ho was rejected and it was concluded that the sample came from a homogeneous distribution population.

The normality assumption test is not fulfilled, so to know the effects of using virtual reality media on learning outcomes using non-parameterized tests. The non-parametric test used the SPSS program with the type of paired t-test, namely Kruskal Wallis in Table 7.

Tabel 7. paired t-tes

\begin{tabular}{cccc}
\hline No & Groups & P & Conclusions \\
\hline 1 & Pre-Tes & 0,000 & *Significan \\
2 & Pos-Tes & & \\
\hline
\end{tabular}


The results of the research hypothesis test using a paired t-test with Kruskal Wallis obtained results of the significance of 0,000 or smaller than 0.05 . These results indicate that virtual reality media influences student learning outcomes. Based on the comparison of learning outcomes the average post-test is greater than the pre-test.

\section{Completion of Learning Outcomes}

Second is the achievement of learning outcomes for KKM. The results of the comparison between learning outcomes with KKM are summarized in Table 8.

Table 8. Comparison of post-test learning outcomes with KKM

\begin{tabular}{ccccc}
\hline Target of KKM & \multicolumn{4}{c}{ Learning Outcomes } \\
\cline { 2 - 5 } & $\begin{array}{c}\text { Total } \\
\text { Data }\end{array}$ & Max. & Min. & Average \\
\hline 75 & 22 & 100 & 65 & 88,18 \\
\hline
\end{tabular}

The average learning outcomes after using the reality virtual media 88.18 while the KKM values that have been determined are 75 . It can be concluded that learning physics using virtual reality media can reach a predetermined KKM.

\section{Classical Completeness}

Third is classical completeness, based on table 8. To find out the percentage of classical completeness always using virtual reality media summarized in Figure 3. Based on Figure 3 The percentage of classical completeness that is equal to $86 \%$ while students who do not complete number 3 with a percentage level of $14 \%$. Thus, it can be concluded that learning physics using virtual reality media can achieve classical completeness because the percentage of completeness can exceed $75 \%$ of students.

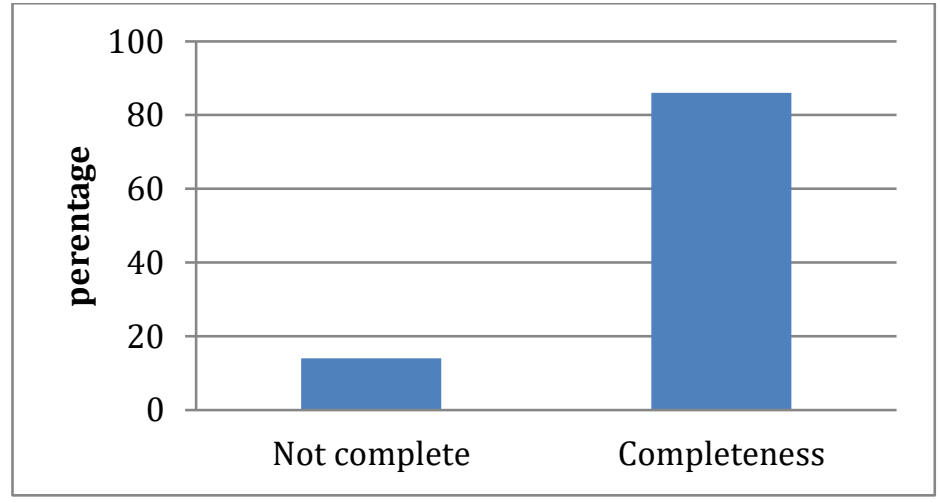

Figure 3. Percentage of classical completeness after using virtual reality media

\section{Discussion}

In this study, digital media is not in the form of online media but media designed to use software to replace video media during solar system learning with digital virtual reality media. In contrast to online digital-based learning (Schmid \& Petko, 2019). Digital media is more focused on the use of software in the form of virtual reality, measured by the effectiveness of three main factors, namely the effect of learning outcomes, KKM, and classical completeness.

First, the influence of virtual reality media on cognitive learning outcomes. Based on the results of the t-test with a significance level of 0.05 calculated by SPSS, the results obtained were 0.00 . Specifically, the influence has been summarized in table 4, namely the maximum target score with a score of 100 , for an average pretest of only 52, 27 while the posttest class average reached 88.18. Thus, students who use virtual reality media are better able to master the concept of solar matter cognitively compared to learning before applying virtual reality media. 
These findings reinforce the results of previous studies, learning media can also have an impact on cognitive, social, and emotional competence (Balkun, 2011). Learning using virtual reality learning media affects students' cognitive (Leder et al., 2019). So that the target effectiveness of one of the elements is the cognitive ability of students in the cognitive domain is achieved.

Second, the learning outcomes exceed the minimum completeness criteria (KKM), which is a score of 75 . Based on the results of the post-test, the average learning outcomes after using virtual reality media are 88.18 while the KKM value that has been determined is 75 . Thus, students in one class are using virtual reality media has exceeded the minimum target cognitive outcomes that have been determined.

The effectiveness of learning outcomes is influenced by the goals and knowledge of students. The effectiveness of student knowledge is measured after the teacher conveys a subject matter discussion on learning (Hamdani, 2011). The research process has applied the measurement principle, the minimum target achievement has been determined that a score of 75 has been reached so that the virtual reality media is effective.

Third, learning outcomes exceed the classical completeness of $75 \%$. Based on the posttest results, the percentage of classical completeness that is equal to $86 \%$ complete number 19 while students who do not complete number 3 with a percentage level of $14 \%$. Thus, students in a class that uses virtual reality media who understand concepts in a cognitive way above a predetermined standard are far more numerous than students under a standard of cognitive understanding.

The number of students who have cognitive understanding above the standard has been set apart from the role of virtual reality media that has been researched (Leder et al., 2019). Theoretically, the use of virtual reality media is better than using video media because it is more able to provide a real experience to users that can encourage generative processing. Other things can be explained that they can provide a deeper understanding so that they can produce higher retention and transfer of knowledge.

Based on the three factors of the effectiveness of learning outcomes, it can be concluded that learning physics uses virtual reality media effectively on learning outcomes. The effectiveness of cognitive learning outcomes is inseparable from the benefits of using learning media, namely as an intermediary between teachers and students in understanding learning material to be more effective and efficient so that learning material is quickly accepted by students and arouses interest in learning more than the target material (Musfikon, 2012). The results of this study reinforce previous research, namely virtual reality media can influence students' cognitive knowledge (Leder et al., 2019; Alahabi, 2016; Passig, D. Tzuriel, D. \& Eshel-Kedmi, 2016; Webster, 2016).

Based on observations, students are more active in the learning process. During the learning process students focus on being able to use virtual reality media to minimize sleepiness, discussion, and other activities outside of learning. Students independently explore the material presented in virtual box media. Presentation of planets in three dimensions so that students can understand deeply the order of the planets from depressed to the farthest to the sun, students can rotate $360^{\circ}$ to find the position of the planets. Students who still need certain planetary information can move towards it and can access information repeatedly. A more interactive virtual reality media design makes students happier during the learning process. Thus virtual reality media can provide benefits to foster independent learning activities by providing learning experiences to students (Smaldino S. E, Deborah L. L, 2011).

Based on facts in observing learning, students are very interested and happy to know information content from virtual reality media independently. These observations indicate that virtual reality can provide opportunities for students to try without coercion from others (Puschmann, 2015). Because the principle of digital media will motivate students to independently learn to explore information or find solutions to this task, it shows that students are skilled in using digital (Schmid \& Petko, 2019). This finding reinforces previous research that learning using virtual reality media impacts student learning motivation (Makransky, G. Bonde, M. T. Wulff, J. S. G. Wandall, J. Hood, M. Creed, 2016; Makransky, G., Thisgaard, M. W., \& Gadegaard, 2016; Thisgaard, M. \& Makransky, 2017; Shapira, Amores, \& Benavides, 2016). So that virtual reality 
media teaching strategies can create interactive-active classes, teaching efficiency can be achieved and measurable levels of material achievement (Pekrun, 2016; Holley, Hobbs, \& Menown, 2016).

Based on the facts in the observation of learning, students are very interested and happy to So that it can affect the increase in learning outcomes. The number of 22 students tested using virtual reality media was only one student who did not experience an increase of $95 \%$ of students who used virtual reality media on the subject of the solar system experienced an increase in grades figure.

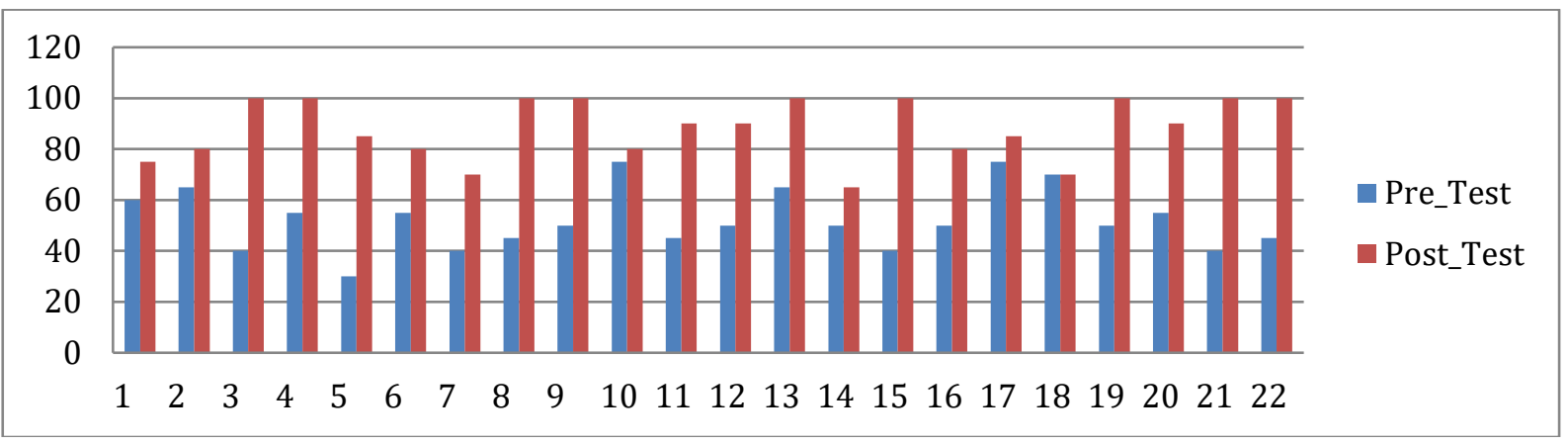

Figure 4. Increased learning outcomes in using virtual reality media

Limitations in this study were the minimum number of students in the study, and only use one class in the study and measurement only in the cognitive domain. The effect of the treatment test was using a non-parametric test due to abnormal posttest data. Learning achievement was only seen in the cognitive domain, not measuring the attitude of students' skills. The implication of this finding was when conducting research using virtual reality media to increase the number of research subjects by comparing it with other groups. In addition to examining other skills such as digital literacy or student communication skills.

\section{Conclusion}

Based on the research hypothesis and the results of testing the hypothesis as described previously, it can be concluded that learning physics using effective virtual reality media on learning outcomes. Classical learning completeness obtained a percentage of results included in the excellent category. This research is still limited to measuring the cognitive domain, with the largest number of samples. Recommendation to educators and researchers, it is advisable to conduct similar research by paying attention to weaknesses or limitations in this study, for example by adding/expanding research samples, measuring students' spatial abilities and memory abilities.

\section{References}

Alahabi, W. S. (2016). Virtual reality systems enhance students' achievements in engineering education. Behaviour \& Information Technology, 35(11), 919-925. https://doi.org/http:// doi.org/10.1080/0144929X.2016.1212931

Arsyad. (2013). Media pembelajaran. PT. Raja Grafindo Persada.

Ashfaq Amin, Diane Gromala, Xin Tong, and C. S. (2016). Immersion in Cardboard VR Compared to a Traditional Head-Mounted Display. In Virtual, Augmented and Mixed Reality (Vol. 2, Issue January, pp. 14-21). https://doi.org/10.1007/978-3-319-39907-2

Bailey, J. O., \& Bailenson, J. N. (2017). Immersive Virtual Reality and the Developing Child. In Cognitive Development in Digital Contexts. Elsevier Inc. https://doi.org/10.1016/B978-0-12809481-5.00009-2

Balkun, M. M. (2011). Teaching with Digital Media: Widening the Framework. Transformations, 22(1), 15-24,143. 
Breedt, S., \& Labuschagne, M. J. (2019). Preparation of nursing students for operating room exposure: A South African perspective. African Journal of Health Professions Education, 11(1), 22. https://doi.org/10.7196/ajhpe.2019.v11i1.1072

Buttussi, F., \& Chittaro, L. (2018). Effects of Different Types of Virtual Reality Display on Presence and Learning in a Safety Training Scenario. IEEE Transactions on Visualization and Computer Graphics, 24(2), 1063-1076. https://doi.org/10.1109/TVCG.2017.2653117

Chittaro, L., \& Buttussi, F. (2015). Assessing knowledge retention of an immersive serious game vs. A traditional education method in aviation safety. IEEE Transactions on Visualization and Computer Graphics, 21(4), 529-538. https://doi.org/10.1109/TVCG.2015.2391853

Clark, B. Tanner-Smith, E. Killingsworth, S. (2016). Digital games, design, and learning: A systematic review and meta-analysis. Review of Educational Research, 86(1), 79-122. https://doi.org/https://doi.org/10.3102/0034654315582065.

Dahsah \& Phonphok. (2012). Students' conception on sizes and distances of the earth-moon-sun models. European Journal of Social Sciences, 32(4), 583-597.

DeJong. (2017). Instruction based on computer simulations and virtual laboratories. Handbook of research on learning and instruction. Routledge.

Derlina, D., \& Mihardi, S. (2015). Implementation Of Inquiry Training Model In Learning Physics To Improve Student Formal Thinking Ability. Jurnal Pendidikan Fisika Indonesia, 11(2), 162169. https://doi.org/10.15294/jpfi .v11i2.4679

Gavish, N., Gutiérrez, T., Webel, S., Rodríguez, J., Peveri, M., Bockholt, U., \& Tecchia, F. (2015). Evaluating virtual reality and augmented reality training for industrial maintenance and assembly tasks. Interactive Learning Environments, 23(6), 778-798. https://doi.org/10.1080/10494820.2013.815221

Hamdani. (2011). Strategi Belajar Mengajar. Pustaka Setia.

Hasanah, T. A. N., Huda, C., \& Kurniawati, M. (2017). Pengembangan Modul Pembelajaran Fisika Berbasis Problem Based Learning (PBL) pada Materi Gelombang Bunyi untuk Siswa SMA Kelas XII. Momentum: Physics Education Journal, 1(1), 56. https://doi.org/10.21067/mpej.v1i1.1631

Hegarty, M. (2010). Components of spatial intelligence. Psychology of Learning and Motivation, 52, 265-296.

Hidayatullah, S. (2018). Konsep Ilmu Pengetahuan Syed Hussein Nashr: Suatu Telaah Relasi Sains Dan Agama. Jurnal Filsafat, 28(1), 113. https://doi.org/10.22146/jf.30199

Hirsh-pasek, K., Zosh, J. M., Michnick, R., Gray, J. H., \& Robb, M. B. (2015). Putting Education in "Educational "Apps: Lessons From the Science of Learning. https://doi.org/10.1177/1529100615569721

Holley, D., Hobbs, M., \& Menown, C. (2016). The Augmented Library: Motivating STEM Students. Networks, 19(19), 77-84.

Jang, S., Vitale, J. M., Jyung, R. W., \& Black, J. B. (2017). Direct manipulation is better than passive viewing for learning anatomy in a three-dimensional virtual reality environment. Computers and Education, 106, 150-165. https://doi.org/10.1016/j.compedu.2016.12.009

Kustijono, R., \& HM., W. E. (2014). Pandangan Guru Terhadap Pelaksanaan Kurikulum 2013 Dalam Pembelajaran Fisika Smk Di Kota Surabaya. Jurnal Penelitian Fisika Dan Aplikasinya (JPFA), 4(1), 1. https://doi.org/10.26740/jpfa.v4n1.p1-14

Lackey, S. J., Salcedo, J. N., Szalma, J. L., \& Hancock, P. A. (2016). The stress and workload of virtual reality training: the effects of presence, immersion and flow. Ergonomics, 59(8), 10601072. https://doi.org/10.1080/00140139.2015.1122234

Leder, J., Horlitz, T., Puschmann, P., Wittstock, V., \& Schütz, A. (2019). Comparing immersive 
virtual reality and powerpoint as methods for delivering safety training: Impacts on risk perception, learning, and decision making. Safety Science, 111(July), 271-286. https://doi.org/10.1016/j.ssci.2018.07.021

Makransky, G., Thisgaard, M. W., \& Gadegaard, H. (2016). Virtual simulations as preparation for lab exercises: Assessing learning of key laboratory skills in microbiology and improvement of essential non-cognitive skills. PLoS One, 11(6). https://doi.org/http://dx.doi.org/10.1371/journal.pone.0155895.

Makransky, G. Bonde, M. T. Wulff, J. S. G. Wandall, J. Hood, M. Creed, P. A. et al. (2016). Simulation based virtual learning environment in medical genetics counseling: An example of bridging the gap between theory and practice. Medical Education, 16(1), 98-106.

Makransky, G. Lilleholt. (2017). Development and validation of the multimodal presence scale for virtual reality environments: A confirmatory factor analysis and item response theory approach. Computers in Human Behavior, 72(1), 276-285. https://doi.org/http://doi.org/10.1016/j.chb.2017.02.066.

Musfikon. (2012). Pengembangan Media Dan Sumber Pembelajaran. PT Prestasi Pustakarya.

Norman, E., \& Furnes, B. (2016). The relationship between metacognitive experiences and learning: Is there a difference between digital and non-digital study media? Computers in Human Behavior, 54, 301-309. https://doi.org/10.1016/j.chb.2015.07.043

Nur. (2015). Belajar dengan Pendekatan PAILKEM. Bumi Aksara.

Nurjanah, S., \& Poernomo, J. B. (2016). Efektivitas model pembelajaran kooperatif tipe TTW dengan TSTS terhadap hasil belajar materi teori kinetik gas. Phenomenon, 6(2). https://doi.org/http://dx.doi.org/10.21580/phen.2016.6.2.1062

Papachristos, N. M., Vrellis, I., \& Mikropoulos, T. A. (2017). A Comparison between Oculus Rift and a Low-Cost Smartphone VR Headset: Immersive User Experience and Learning. Proceedings - IEEE 17th International Conference on Advanced Learning Technologies, ICALT 2017, 477-481. https://doi.org/10.1109/ICALT.2017.145

Passig, D. Tzuriel, D. \& Eshel-Kedmi, G. (2016). Improving children's cognitive modi fiability by dynamic assessment in 3D Immersive Virtual Reality environments. Computers \& Education, 95, 296-308.

Pekrun, R. (2016). Emotions at school. In K. R. Wentzel, \& D. B. Miele (Eds.). Handbook motivation. Routledge.

Plummer, J. D., Palma, C., Flarend, A., Rubin, K. A., Ong, Y. S., Botzer, B., McDonald, S., \& Furman, T. (2015). Development of a Learning Progression for the Formation of the Solar System. International Journal of Science Education, 37(9), 1381-1401. https://doi.org/10.1080/09500693.2015.1036386

Poniman, P. (2016). Pembelajaran Fisika Berbasis Kompetensi Life Skill Kelas XII IPA.1 MAN 1 Lampung Selatan. Jurnal IImiah Pendidikan Fisika Al-Biruni, 5(1), 71. https://doi.org/10.24042/jpifalbiruni.v5i1.107

Puschmann, C. (2015). The form and function of quoting in digital media. Discourse, Context and Media, 7, 28-36. https://doi.org/10.1016/j.dcm.2015.01.001

Renninger, K. A; \& Hidi, S. E. (2016). The power of interest for motivation and engagemen. Routledge.

Sarah, S. (2019). Pemetaan potensi lokal kabupaten Wonosobo untuk pembelajaran fisika sekolah menengah atas (SMA). Edusains, 11(1), 121-131. https://doi.org/https://doi.org/10.15408/es.v1111.9073

Schmid, R., \& Petko, D. (2019). Does the use of educational technology in personalized learning environments correlate with self-reported digital skills and beliefs of secondary-school 


\section{$\begin{array}{lllll}\text { students? } & \text { Computers } & \text { 75-86. }\end{array}$}

https://doi.org/10.1016/j.compedu.2019.03.006

Schneps, M. H., Ruel, J., Sonnert, G., Dussault, M., Griffin, M., \& Sadler, P. M. (2014). Conceptualizing astronomical scale: Virtual simulations on handheld tablet computers reverse misconceptions. Computers and Education, 70, 269-280. https://doi.org/10.1016/j.compedu.2013.09.001

Shapira, L., Amores, J., \& Benavides, X. (2016). TactileVR: Integrating Physical Toys into Learn and Play Virtual Reality Experiences. Proceedings of the 2016 IEEE International Symposium on Mixed and Augmented Reality, ISMAR 2016, 100-106. https://doi.org/10.1109/ISMAR.2016.25

Shen, J. \& Confrey, J. (2010). Justifying alternative models in learning astronomy: A study of K-8 teachers' understanding of frames of reference. ,. International Journal of Science Education, 32,(1), 1-29.

Shen \& Confrey. (2010). Justifying alternative models in learning astronomy: A study of K-8 teachers' understanding of frames of reference. International Journal of Science Education, $32,1-9$.

Shi, Y., Du, J., Ahn, C. R., \& Ragan, E. (2019). Impact assessment of reinforced learning methods on construction workers' fall risk behavior using virtual reality. Automation in Construction, 104(May), 197-214. https://doi.org/10.1016/j.autcon.2019.04.015

Smaldino S. E, Deborah L. L, J. D. R. (2011). Instructional Technology \& Media For Learning. Kencana.

Susanti, W., \& Jatmiko, B. (2016). Implementasi Model Pembelajaran Kooperatif Tipe Tai ( Team Assisted Individualization ) Untuk Meningkatkan Hasil Belajar I . Pendahuluan Pendidikan adalah sebuah proses untuk mengubah jati diri seorang peserta didik untuk lebih maju [ 1 ]. Keberhasilan pe. Jurnal Penelitian Fisika Dan Aplikasinya (JPFA), 06(01). https://doi.org/http://dx.doi.org/10.26740/jpfa.v6n1.p26-33

Susilowati. (2017). Pemanfaatan Teknologi 3d Virtual Reality Pada Pembelajaran Matematika Tingkat Sekolah Dasar. Jurnal IImiah Nero, 37-43.

Thisgaard, M. \& Makransky, G. (2017). Virtual learning simulations in high School: Effects on cognitive and non-cognitive outcomes and implications on the development of STEM academic and career choice. Frontiers in Psychology, 8.

Valdesolo, P., Shtulman, A., \& Baron, A. S. (2017). Science Is Awe-Some: The Emotional Antecedents of Science Learning. Emotion Review, 9(3), 215-221. https://doi.org/10.1177/1754073916673212

Webster, R. (2016). Declarative knowledge acquisition in immersive virtual learning environments. Interactive Learning Environments, 24(6), 1319-1333.

Williamson \& Willoughby. (2012). Student understanding of gravity in introductory college astronomy. Astronomy Education Review, 11. https://doi.org/010105-1-010105-12.

Yu, K. C., Sahami, K., Denn, G., Sahami, V., \& Sessions, L. C. (2016). Immersive Planetarium Visualizations For Teaching Solar System Moon Concepts To Undergraduates. Journal of Astronomy \& Earth Sciences Education (JAESE), 3(2), 93. https://doi.org/10.19030/jaese.v3i2.9843

Yu ka Sahami \& Denn G. (2010). Student ideas about Kepler's laws and planetary orbital motions. Astronomy Education Review, 9. https://doi.org/010108-1-010108-17

Yusriyah, Y. (2015). The Reconstruction of Islamic Theology in The Unity of Sciences. Walisongo: Jurnal Penelitian Sosial Keagamaan, 23(2), 401. https://doi.org/10.21580/ws.23.2.286 